San Jose State University

SJSU ScholarWorks

Master's Theses

Master's Theses and Graduate Research

1994

\title{
Effects of black-tailed deer, Odocoileus hemionus, on vegetative understory at Asilomar State Beach and conference grounds
}

Emily J. Buffon

San Jose State University

Follow this and additional works at: https://scholarworks.sjsu.edu/etd_theses

\section{Recommended Citation}

Buffon, Emily J., "Effects of black-tailed deer, Odocoileus hemionus, on vegetative understory at Asilomar State Beach and conference grounds" (1994). Master's Theses. 894.

DOI: https://doi.org/10.31979/etd.m3ac-xjqj

https://scholarworks.sjsu.edu/etd_theses/894

This Thesis is brought to you for free and open access by the Master's Theses and Graduate Research at SJSU ScholarWorks. It has been accepted for inclusion in Master's Theses by an authorized administrator of SJSU ScholarWorks. For more information, please contact scholarworks@sjsu.edu. 


\section{INFORMATION TO USERS}

This manuscript has been reproduced from the microfilm master. UMI films the text directly from the original or copy submitted. Thus, some thesis and dissertation copies are in typewriter face, while others may be from any type of computer printer.

The quality of this reproduction is dependent upon the quality of the copy submitted. Broken or indistinct print, colored or poor quality illustrations and photographs, print bleedthrough, substandard margins, and improper alignment can adversely affect reproduction.

In the unlikely. event that the author did not send UMI a complete manuscript and there are missing pages, these will be noted. Also, if unauthorized copyright material had to be removed, a note will indicate the deletion.

Oversize materials (e.g., maps, drawings, charts) are reproduced by sectioning the original, beginning at the upper left-hand corner and continuing from left to right in equal sections with sroall overlaps. Each original is also photographed in one exposure and is included in reduced form at the back of the book.

Photographs included in the original manuscript have been reproduced xerographically in this copy. Higher quality $6^{\prime \prime} \times 9^{n}$ black and white photographic prints are available for any photographs or illustrations appearing in this copy for an additional charge. Contact UMI directly to order.

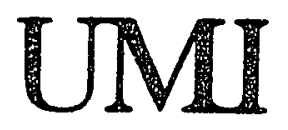




\title{
EFFECTS OF BLACK-TAILED DEER, ODOCOILEUS HEMIONUS, ON VEGETATIVE UNDERSTORY AT ASILOMAR STATE BEACH AND CONFERENCE GROUNDS
}

\author{
A Thesis \\ Presented to \\ The Faculty of the Department of Biological Sciences \\ San Jose State University \\ In Partial Fulfillment \\ of the Requirements for the Degree \\ Miaster of Science
}

By

Emily J. Buffon

December, 1994 
UMI Number: 1361152

UMI Microform Edition 1361152

Copyright 1995, by UMI Company. All rights reserved.

This microform edition is protected against unauthorized copying under Title 17, United States Code.

\section{UMI}

300 North Zeeb Road

Ann Arbor, MI 48103 
(C) 1994

Emily Jean Buffon

ALL RIGHTS RESERVED 
APPROVED FOR THE DEPARTMENT OF BIOLOGICAL SCIENCES

William ERos

Dr. William E. Bros

Dr. Michael J. Kutilek

Rodney. My at

APPROVED FOR THE UNIVERSITY

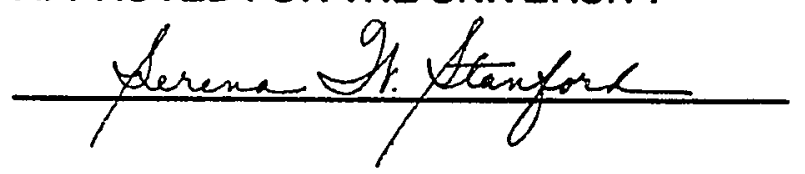




\begin{abstract}
EFFECTS OF BLACK-TAILED DEER, ODOCOILEUS HEMIONUS, ON THE UNDERSTORY VEGETATION AT ASILOMAR STATE BEACH AND CONFERENCE GROUNDS
\end{abstract}

By Emily J. Buffon

The California Department of Parks and Recreation is concerned that the Columbian black-tailed deer (Odocoileus hemionus) population at Asilomar State Park is having a negative impact on the understory vegetation, and in particular on restoration efforts. In this study, we compared plant height, species composition, and ground cover over a one year period between plots that excluded deer via an exclosure to similar plots that allowed deer access. We also conducted a deer census using total area counts.

Results indicated that deer reduce plant height; herbs were affected in the spring, shrubs were affected in the fall, and grass was shorter over the year. Impacts on restoration were mixed. Deer have a negative effect on some desirable native species and also on some undesirable invasive non-native species. Deer did not affect plant cover over the one year period. 


\section{ACKNOWLEDGMENTS}

Many people contributed to the completion of this thesis. First, I want to thank the members of my thesis committee. Dr. Bill Bros skillfully and with humor guided me through the entire process. Dr. Mike Kutilek assisted in the planning, the preliminary survey, and the final editing. Dr. Rod Myatt, helped with the final editing and also, with humor and support, taught me about California plants and the enjoyment of life.

The Asilomar Operating Corporation provided funding for this study. Tom Moss, Asilomar ecologist, provided direction, knowledge, and encouragement. A special thanks to the park staff at Asilomar, especially Tisa and Theima, who worked long and hard building the exclosures.

On a personal level, I want to thank my mother, who went back to school later in life, and thus, showed me that it could be done; my mother also sent me frequent checks that helped to lighten the load. I want to acknowledge my son, Sierra, whose sunny presence cheered me on. Thanks also go to my friend John who provided support, encouragement, direction, and financial assistance. And last, I would like to thank Kris Timmerman, my friend and colleague, who shared her time and knowledge and also her ear and emotional support in times of discouragement. 


\section{TABLE OF CONTENTS}

ABSTRACT $\ldots \ldots \ldots \ldots \ldots \ldots \ldots \ldots \ldots \ldots \ldots \ldots \ldots \ldots \ldots \ldots \ldots \ldots \ldots \ldots \ldots \ldots \ldots$

ACKNOWLEDGMENTS $\ldots \ldots \ldots \ldots \ldots \ldots \ldots \ldots \ldots \ldots \ldots \ldots$ iv

TABLE OF CONTENTS $\ldots \ldots \ldots \ldots \ldots \ldots \ldots \ldots \ldots \ldots \ldots \ldots \ldots \ldots$

LIST OF FIGURES $\ldots \ldots \ldots \ldots \ldots \ldots \ldots \ldots \ldots \ldots \ldots \ldots \ldots \ldots$ vi

LIST OF TABLES $\ldots \ldots \ldots \ldots \ldots \ldots \ldots \ldots \ldots \ldots \ldots \ldots \ldots \ldots \ldots$ vii

INTRODUCTION $\ldots \ldots \ldots \ldots \ldots \ldots \ldots \ldots \ldots \ldots \ldots \ldots \ldots \ldots \ldots \ldots$

METHODS $\ldots \ldots \ldots \ldots \ldots \ldots \ldots \ldots \ldots \ldots \ldots \ldots \ldots \ldots \ldots \ldots \ldots \ldots \ldots$

Study site $\ldots \ldots \ldots \ldots \ldots \ldots \ldots \ldots \ldots \ldots \ldots \ldots \ldots \ldots \ldots \ldots \ldots$

Impact of browsing on vegetation $\ldots \ldots \ldots \ldots \ldots \ldots \ldots \ldots \ldots \ldots$

Doer census ........................................ 14

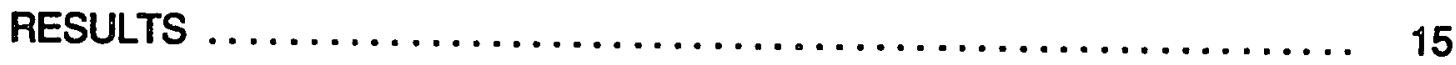

Understory-Upland $\ldots \ldots \ldots \ldots \ldots \ldots \ldots \ldots \ldots \ldots \ldots \ldots \ldots \ldots \ldots \ldots$

Understory-Seaside $\ldots \ldots \ldots \ldots \ldots \ldots \ldots \ldots \ldots \ldots \ldots \ldots \ldots \ldots \ldots$

Deer census ............................... 29

DISCUSSION $\ldots \ldots \ldots \ldots \ldots \ldots \ldots \ldots \ldots \ldots \ldots \ldots \ldots \ldots \ldots \ldots \ldots \ldots \ldots$

LITERATURE CITED $\ldots \ldots \ldots \ldots \ldots \ldots \ldots \ldots \ldots \ldots \ldots \ldots \ldots \ldots \ldots$ 


\section{LIST OF FIGURES}

Figure 1. Diagrams of fenced plot. A. Fenced plot, top view.

B. Fenced plot, side view.

Figure 2. Multivariate effect from RCB - MANOVA of mean plant height and standard deviation in plant heights for Grass, Herbs and Shrubs in the Upland Area in April 1993. The main effect is Treatment (Deer present or Deer absent). The Block is a matched pair site.

Figure 3. Multivariate effect from RCB - MANOVA of frequency of occurrence of species in plot quadrats for Seaside Area in April 1993. The main effect is Treatment (Deer present or Deer absent). The Block is a matched pair site.

Figure 4. Significant treatment effect from RCB ANOVA for occurrence of Lotus and Mock Heather in plot quadrats for Seaside in June 1993. Main effect is Treatment (Deer present and Deer absent) and Block is the matched pair site.

Figure 5. Mean deer counts for the months, December 1992 to September 1993. 


\section{LIST OF TABLES}

Table 1. Plant list for the Upland and Seaside sampling areas (common and scientific names). Scientific names of plants follow the Jepson Manual 1993 (Hickman 1993). ........... 5

Table 2. Multivariate test (RCB - MANOVA) of Mean Plant Height and Standard Deviation in Plant Heights for three categories of plants (Grass, Herb and Shrub) in the Upland Area for April and July 1993. ..................... 16

Table 3. Univariate tests (RCB ANOVA) of Mean Plant Height and Standard Deviation in Plant Heights for three categories of plants (Grass, Herb, and Shrub) in the Upland Area for April and July 1993.

Table 4. Occurrence of Selected Species in plot quadrats in the Upland Area.

Table 5. Multivariate test (RCB - MANOVA) of Species composition in the Seaside Area.

Table 6. Univariate tests (RCB ANOVA) of Occurrence of Specific Species in plot quadrats in the Seaside Area for June 1993 (Deer present/absent). 


\section{INTRODUCTION}

Conservation biologists are acknowledging a growing and difficult problem; opportunistic native species such as deer (Odocoileus spp.) that can thrive in close proximity to human development may cause the decline and extirpation of more sensitive and rare native species (Alverson 1988, Diamond 1992, Garrott et al. 1993). Overbrowsing by deer can cause shifts in plant species composition (Graham 1958, Alverson et al. 1988, Tilghman 1989, Anderson 1994). Anderson (1994) documented the decline of white-flowered trillium (Trillium grandiflorum) from the understory of a deciduous forest in Illinois due to a high intensity of deer browsing.

The nature and the severity of the impact of deer have been shown to vary with deer density (Graham 1958, Beals et al. 1960, Hough 1965, Anderson and Loucks 1979, Tilghman 1989). Deer favor certain plant species at different times of the year and individual plant species vary in their sensitivity to browsing pressure. At higher deer densities, biomass intake is greater and less favored species may be impacted. In a hardwood forest in Pennsylvania, sites with low white-tailed deer density had a higher abundance of blackberries and few ferns, while sites with higher deer density had fow blackberries and thick patches of fern cover (Tilghman 1989). 
Tilghman (1989) found that forest density mediated the effect of deer browsing; in a thinned hardwood forest, deer densities of 15 deer $/ \mathrm{km}^{2}$ caused changes in plant height and species composition, but in an uncut forest only deer densities of 30 deer $/ \mathrm{km}^{2}$ produced a comparable effect. Graham (1958) reported high white-tailed deer densities to be favorable to the growth of desirable species in some areas of a forest in Michigan and detrimental in others.

The California Department of Parks and Recreation (CDPR) directs park ecologists to attempt to restore State Parks to an ecological condition that existed before the settlement of Europeans. Restoration involves the protection and cultivation of native plants and animals and the eradication of invasive nonnative biota. At Asilomar State Beach and Conference Grounds, Pacific Grove, California, the CDPR has organized an extensive restoration effort incorporating the dunes and Monterey pine (Pinus radiata) forest (Smith 1992). The restoration has included the propagation and planting of native plants and the eradication of invasive non-native plants. The CDPR is concerned that the native Columbian black-tailed deer (Odocoileus hemionus columbianus) population may be contributing to the loss and replacement of the native flora by exotic species, thus limiting the success of the restoration efforts at Asilomar.

Private efforts by local citizens to feed the deer population in the neighborhoods surrounding Asilomar may have contributed to a deer density 
problem. Supplemental feeding can greatly increase population size (Ozoga and Verme 1982). Extensive private feeding was practiced for many years in a neighborhood next to Asilomar, but some of it was stopped in the summer of 1992. An increased deer population may put additional pressure on an already heavily browsed understory.

The primary focus of this study was to assess the impact of deer on the understory vegetation at Asilomar. We compared plant height, species composition, and ground cover between plots that excluded deer via an exciosure to similar plots that allowed deer access. The design was set up as a series of matched pair plots. A difference in plant height between matched plots would show whether deer browsing was inhibiting or enhancing plant growth. Shorter plants would provide less browse and might indicate less plant vigor. By monitoring changes in species composition between matched plots, we assessed whether the deer were adversely effecting restoration efforis.

We censused the resident deer population in the park. By comparing our census data to an earlier census taken at Asilomar (Smith 1992), as well as published censuses taken in similar habitats (Alverson 1988), we could get an indication if the population was abnormally high, declining, or stable. We distinguished fawns from adults in our count. A high percentage of fawns would indicate short-term population growth. 


\section{METHODS}

\section{Study site}

The study area encompassed approximately 40 ha (100 acres) of deer habitat in an open Monterey Pine forest In Asilomar State Beach and Conference Grounds, Pacific Grove, California. The climate is typical of the northwest Pacific coast (Barbour and Major 1977). Summers are cool and foggy, but dry with the highest mean monthly temperatures in September $\left(17^{\circ} \mathrm{C}\right)$. Winters are alternately rainy and clear with slightly cooler temperatures (the lowest mean temperature is $10^{\circ} \mathrm{C}$ ). Average annual precipitation is about 465 $\mathrm{mm}$ (18 inches)

The study area was divided into two sampling sites, Upland and Seaside habitats. Each site was characterized by a distinct soil type and assemblage of understory plant species (Table 1). Restoration efforts at each site reflect the characteristics of the area. Monterey Pines dominate the overstory at both sites. Coast Live Oak (Quercus agrifolia) is the second most important tree species. Oaks of all ages are scattered throughout the park. Areas of the grounds covered by structures (e.g., buildings, parking lots) were excluded from sampling.

The Upland area is farther inland from the beach and is dominated by grasses and sedges: rattlesnake grass (Briza maxima), Italian rye, (Lolium multiflorum), ripgut (Bromus diandrus), oats (Avena fatua), giant rye (Elymus 
Table 1. Plant list for the Uplant and Seaside sampling areas (common and scientific names). Scientific names of plants follow the Jepson Manual 1993 (Hickman 1993). "Non-native species

\begin{tabular}{|c|c|c|c|}
\hline \multicolumn{2}{|c|}{ UPLAND AREA } & \multicolumn{2}{|c|}{ SEASIDE AREA } \\
\hline Bedstraw & Galium spp. & Beach aster & $\begin{array}{l}\text { Corethrogyne } \\
\text { californica }\end{array}$ \\
\hline Blackberry & Rubus ursinus & Bed straw & Galium spp. \\
\hline Bolander pea & Lathyrus vestitus & Bracken fern & Pteridium aquilinum \\
\hline Bracken fern & Pteridium aquilinum & Common fiddleneck & Amsinckia menziesii \\
\hline $\begin{array}{l}\text { California brome } \\
\text { grass }\end{array}$ & Bromus carinatus & Coyote Bush & Baccharis pilularis \\
\hline Clover & "Melilotus spp. & Douglas iris & Iris douglasiana \\
\hline Coast live oak & Quercus agrifolia & Dune sedge & Carex pansa \\
\hline Cofieeberry & Rhamnus califomica & Fireweed & "Erechtites arguta \\
\hline Douglas Iris & Iris douglasiana & French broom & $\begin{array}{l}\text { "Genista } \\
\text { monspessulana }\end{array}$ \\
\hline Dune sedge & Carex pansa & Iceplant & - Carpobrotus spp. \\
\hline French broom & $\begin{array}{l}\text { "Genista } \\
\text { monspessulana }\end{array}$ & Lotus (woolly) & Lotus heermannii \\
\hline Giant wild rye & Elymus condensatus & Lotus (deerweed) & Lotus scoparius \\
\hline Hedge nettle & Stachys bullata & $\begin{array}{l}\text { Lupine (yellow } \\
\text { bush) }\end{array}$ & Lupinus arboreus \\
\hline Italian rye & "Lolium multiflorum & $\begin{array}{l}\text { Lupine (silver } \\
\text { beach) }\end{array}$ & Lupinus chamissonis \\
\hline Kikuyu grass & $\begin{array}{l}\text { Pennisetum } \\
\text { clandestinum }\end{array}$ & Milk vetch & Astragalus nuttallii \\
\hline Miners lettuce & Montia perfoliata & Mock heather & Ericameria ericoides \\
\hline Monkey flower & Mimulus aurantiacus & Monkey flower & Mimulus aurantiacus \\
\hline Oxalis & "Oxalis spp. & Monterey pine & Pinus radiata \\
\hline Pacific pea & Lathyrus vestitus & Poison oak & $\begin{array}{l}\text { Toxicodendron } \\
\text { diversilobum }\end{array}$ \\
\hline Poison oak & $\begin{array}{l}\text { Toxicodendron } \\
\text { diversilobum }\end{array}$ & Rattlesnake grass & "Briza maxima \\
\hline
\end{tabular}




\begin{tabular}{|c|c|c|c|}
\hline Rattlesnake grass & - Briza maxima & Ripgut grass & - Bromus diandrus \\
\hline Ripgut grass & "Bromus diandrus & Sand mat & $\begin{array}{l}\text { Cardionema } \\
\text { ramosissimum }\end{array}$ \\
\hline Snowberry & $\begin{array}{l}\text { Symphoricarpos } \\
\text { mollis }\end{array}$ & Sagewort & $\begin{array}{l}\text { Artemisia } \\
\text { pycnocephala }\end{array}$ \\
\hline Westem ryegrass & Elymus glaucus & Seaside daisy & Erigeron glaucus \\
\hline Wild cucumber & Marah fabacous & Western ryegrass & Elymus glaucus \\
\hline Wild oat & -Avena fatua & Yamow & Achillea borealis \\
\hline Willow & Salix lasiolepis & & \\
\hline Yerba buena & Satureja douglasii & & \\
\hline
\end{tabular}


condensatus) and dune sedge (Carex pansa). Poison oak (Toxicodendron diversilobum), hedge nettle (Stachys bullata), monkey flower (Mimulus aurantiacus), bedistraw (Galium spp.) and bracken fern (Pteridium aquilinum) are other common species. The soil is classified as loamy sand. Parts of the upland area were formerly commercial and residential and were added to the park in 1972 (Smith 1992). During the residential period, herbicides were used to control poison oak and as a side effect, much of the native understory was destroyed. Since the area has been incorporated into the park, native plants such as poison oak, hedge nettle and monkey flower have been protected, and non-natives such as broom (Genista spp.) and Kikuyu grass (Pennisetum clandestinum) have been treated individually with a herbicide.

The seaside habitat, adjacent to the beach, has sandy soil and the plant species composition is dominated by sagewort (Artemesia pycnocephala), mock heather (Ericameria eriocoides), yarrow (Achillea millefolium), lotus (Lotus spp.), dune sedge (Carex pansa), and rattlesnake grass (Briza maxima). Restoration efforts in the seaside area have included extensive removal of nonnative iceplant (Carpobrotus spp.) and the revegetation of the cleared areas. 


\section{Impact of browsing on vegetation}

To assess the impact of deer an the vegetative understory, we measured plant height and cover, and species composition over a one year period in a series of randomly selected matched pair plots. Each matched pair consisted of two $1 \times 2 \mathrm{~m}$ plots, one of which was enclosed by a fence to exclude deer (Figure 1). The exclosures were approximately two meters high, three meters wide, and four meters long. All fences were constructed with heavy gauge wire mesh with two meter tall metal posts at one meter intervals. Within the center of the exclosure, a $1 \times 2 \mathrm{~m}$ sampling plot was delineated by a metal rod at the center of each one meter side. The unfenced $1 \times 2 \mathrm{~m}$ plots were marked with metal posts at the four corners. The metal rods were covered with white plastic pipe to protect both deer and people from injury. A $1 \times 2 \mathrm{~m}$ grid with thirty-two $25 \mathrm{~cm}$ square quadrats was constructed as a portable measuring tool. The grid was constructed of one-half inch plastic pipe and fine metal wire. To avoid crushing the vegetation while measuring, the grid was held above the vegetation with removable legs fitted to the corners; legs of different length were used to accommodate different heights of vegetation.

To assess plant growth at a site, we examined differences in two measures, average plant height and variation in plant height, between the enclosed and open plots. Average plant height is an indicator of overall biomass in a plot. Variability in plant height is a measure of another type of 


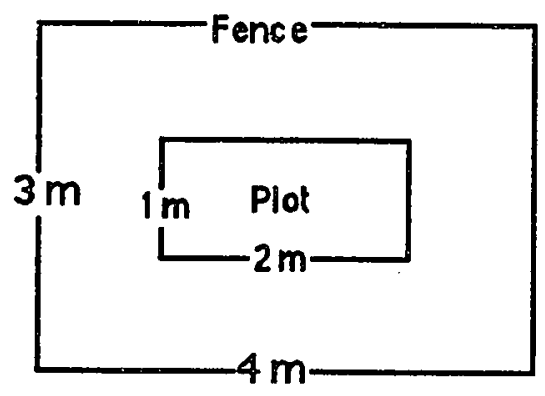

A. Fenced plot, top yiew

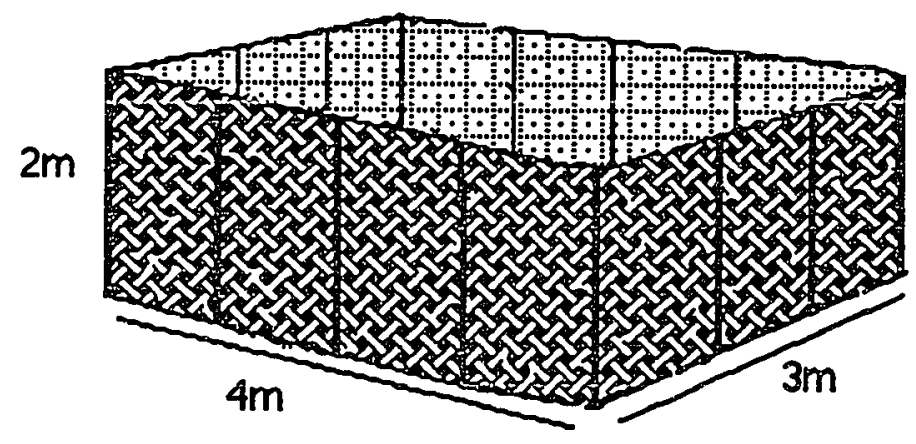

B. Fenced plot, side yiew

Figure 1. Diagrams of fenced plot. A. Fenced plot, top view. B. Fenced plot, side view 
effect; small variation indicates that plants are of uniform height, while high variation indicates large differences in heights among plants within a plot.

To obtain both measures, we selected (randomly) 12 quadrats from the 32 quadrats in a plot and, in each, measured the height of the middlemost plant in each of three categories, Grass, Herb and Shrub. The Grass category included grasses and sedges. The Shrub category was defined as all woody vegetation which included tree saplings. The Herb category included all nonwoody plants that did not fit into the Grass category. For each category, mean plant height and the associated standard deviation were computed from the twelve measurements for each plot of the matched pair. A univariate randomized complete block analysis of variance (RCB ANOVA, Zar, 1981) with site as a block was used to detect changes in both average plant height (Mean) and variation in plant height (Std. dev.) between enclosed and non-enclosed matched plots for each of the three categories: Grass, Herb, and Shrub.

Deer browsing could also have selective effects on the heights of plants among the three categories (e.g. browsing causes a decrease in herb height, but no change in the others). A multivariate randomized complete block analysis of variance (RCB MANOVA, Johnson and Wichern 1982) was used to measure differences in proportions of average plant height and variation in plant height among the three categories between matched pair plots. 
To assess changes in species composition, we measured the relative abundance of plant species in all plots. For each species we recorded presence/absence in each of the thirty-two $25 \mathrm{~cm}^{2}$ quadrats; maximum relative abundance for any species was thirty-two. Root presence was recorded for Grasses and Herbs, and shoot presence was recorded for Shrubs. An RCB ANOVA with site as a block was used to detect changes in relative abundance of the species between enclosed and non-enclosed matched plots. An RCB MANOVA was used to measure differences in proportions (species composition) of the various species between the matched pair plots.

Cover was measured using the line intercept method (Kershaw and Looney 1985) at ground level, one-half meter above ground, and one meter above ground along a $2 \mathrm{~m}$ transect though the center of the $1 \times 2 \mathrm{~m}$ grid. Cover for Grass, Herb or Shrub categories was computed as the sum of the distances that each patch of each category (e.g. Grass) eclipsed a $2 \mathrm{~m}$ line held at ground level or an above ground level. Bare ground was measured at ground level. An RCB ANOVA with site as a block was used to detect changes in cover of the categories (e.g. Bare ground, Grass) between enclosed and non-enclosed matched plots. An RCB MANOVA was used to measure differences in proportions of the three to four categories between the matched pair plots.

All statistical analyses for our paired design included two tests of significance. The main test, the Treatment effect, assesses the difference in the 
understory vegetation between the fenced plots (deer excluded) and the matched unfenced plot. The Block effect, the second statistical test, assesses the degree of variation between all matched pair plot sites for each area (Upland or Seaside). If the Block effect is significant $(p<.05)$, there is high variation among paired plot sites; high variation indicates that the paired plot design was necessary to detect differences between fenced and unfenced plots.

A preliminary survey, utilizing the methods above, was initiated in July, 1992 to determine the optimum sample size (number of matched pair plots) for our design. The ability to detect differences is affected by sample size; the smaller the sample size, the less likely that small differences can be detected. Limitations in space and/or funding place limitations on the upper limits of sample size. The optimum sample size is one that is small enough to be feasible but large enough to detect reasonable differences. The Expected Minimum Detectable Difference (MDD) (Zar, 1981) is a measure of how well a particular test can detect differences between treatments (i.e. deer vs. no deer). Sample variances from the preliminary survey were used to compute the expected minimum detectable differences. We used a sample size of fifteen pairs in the upland habitat. With a sample size of fifteen pairs, we predicted a $90 \%$ probability of detecting a difference of $4-6 \mathrm{~cm}$ for plant height and approximately $20 \mathrm{~cm}$ for cover. Because of limited space in the seaside habitat, 
we used a sample size of thirteen pairs for that area. With thirteen pairs, the detectable differences were approximately the same as the differences for fifteen pairs in the upland habitat.

After randomly selecting a plot site, two plots that appeared similar in plant height, cover and species composition were selected. We took all measurements in each plot and analyzed the measurements to insure equivalency in plant height, plant cover, and species composition between matched pairs. An RCB ANOVA with site as a block was used to insure similarity in plant height and cover. If the null hypothesis was accepted with $p>.05$, the plots were considered equivalent.

Czechanowski's Quantitative Similarity Index was used to measure similarity in species composition between the matched pair plots (Bray and Curtis 1957, Bloom 1981). Matched pair plots with a similarity score $>0.7$ were considered equivalent. If a pair did not meet these criteria, one or both of the paired sites was moved until the criteria was met.

The next phase of the study began in October 1992 with the building of the first fence and continued until our final measurements in September of 1993. Exclosures were constructed for the Upland during the month of October 1992, and baseline measurements to insure equivalency were taken and analyzed for the Upland in the last week of October. After 23 weeks, in the first week of April, a series of measurements were made and analyzed for each of the matched 
pair plots in the Upland area. The measurements were repeated 16 weeks later and reanalyzed in the last week of July. Seaside exclosures were built in November and December 1992, and baseline measurements were taken and analyzed in late December 1992. Repeat measurements for the Seaside sampling area were taken and reanalyzed in June and September of 1993.

\section{Deer census}

We used total area counts to census deer (Dasmann and Taber, 1955). This method could be used because the deer in the park spend most of their time in a small area and the deer move very little when approached (Dasmann, 1953). One person walked in a crisscross fashion through the park to tally deer. Counts were taken in the morning or evening as these times have been established as the best observation times (Dasmann and Taber, 1956). Sex and age of deer were recorded. Three categories were recognized: Adult males (included male yearlings as well as oider adult males), Adult females (included female yearlings because they are hard to distinguish from older adult females), and Fawns (deer of either sex less than one year old). Female yearlings do not usually produce fawns (Robinette and Gashwiler, 1950, Crane and Jones, 1953); they ordinarily produce their first fawn when they are two years old. Lumping female yearlings with breeding females impacts the fawn to female ratio (Dasmann and Taber, 1956). If fawn to yearling survival has been high, the fawn 
to female ratio can be interpreted as low, or conversely if the fawn to yearling survival has been low, the fawn to female ratio might appear high.

\section{RESULTS}

\section{Understory-Upland}

During the first five month period (Oct 92-Apr 93) in the Upland area, deer browsed differentially among the three plant height categories: Grass, Herb, and Shrub; grass height and herb height were impacted. The RCB MANOVA indicated a proportional shift in plant height between the three categories (Table 2). The reduction in grass height and herb height were proportionately greater than the reduction in shrub height in the open (deer present) plots (Figure 2). Also, herbs tended to be more uniform in height when deer were present.

For the same five month period, univariate tests confirmed that deer browsing was causing shorter grass, and more uniform grass and herb heights. The RCB ANOVA showed that grass height was significantly lower (Table 3 ) in the open plots $(30.8 \mathrm{~cm})$ than in the enclosed plots $(39.4 \mathrm{~cm})$. The standard deviation in height of grasses and herbs was significantly more uniform in the open plots ( $10.0 \mathrm{~cm}$ and $4.5 \mathrm{~cm}$, respectively) than in the enclosed plots $(12.0 \mathrm{~cm}$ and $9.2 \mathrm{~cm}$, respectively). For the individual univariate tests, neither herb height not shrub height varied significantly between deer and no deer 
Table 2. Multivariate test (RCB - MANOVA) of Mean Plant Height and Standard Deviation in Plant Heights for three categories of plants (Grass, Herb and Shrub) in the Upiand Area.

\begin{tabular}{|c|c|c|c|c|}
\hline SOURCE & WILKS' LAMDA & DF & $\mathbf{F}$ & PROB \\
\hline \multicolumn{5}{|l|}{ For April, 1993} \\
\hline $\begin{array}{l}\text { Deer } \\
\text { Present/Absent }\end{array}$ & 0.258 & 6,9 & 4.313 & 0.025 \\
\hline \multicolumn{5}{|l|}{ For July, 1993} \\
\hline $\begin{array}{l}\text { Deer } \\
\text { Present/Absent }\end{array}$ & 0.474 & 6,9 & 1.663 & 0.236 \\
\hline
\end{tabular}




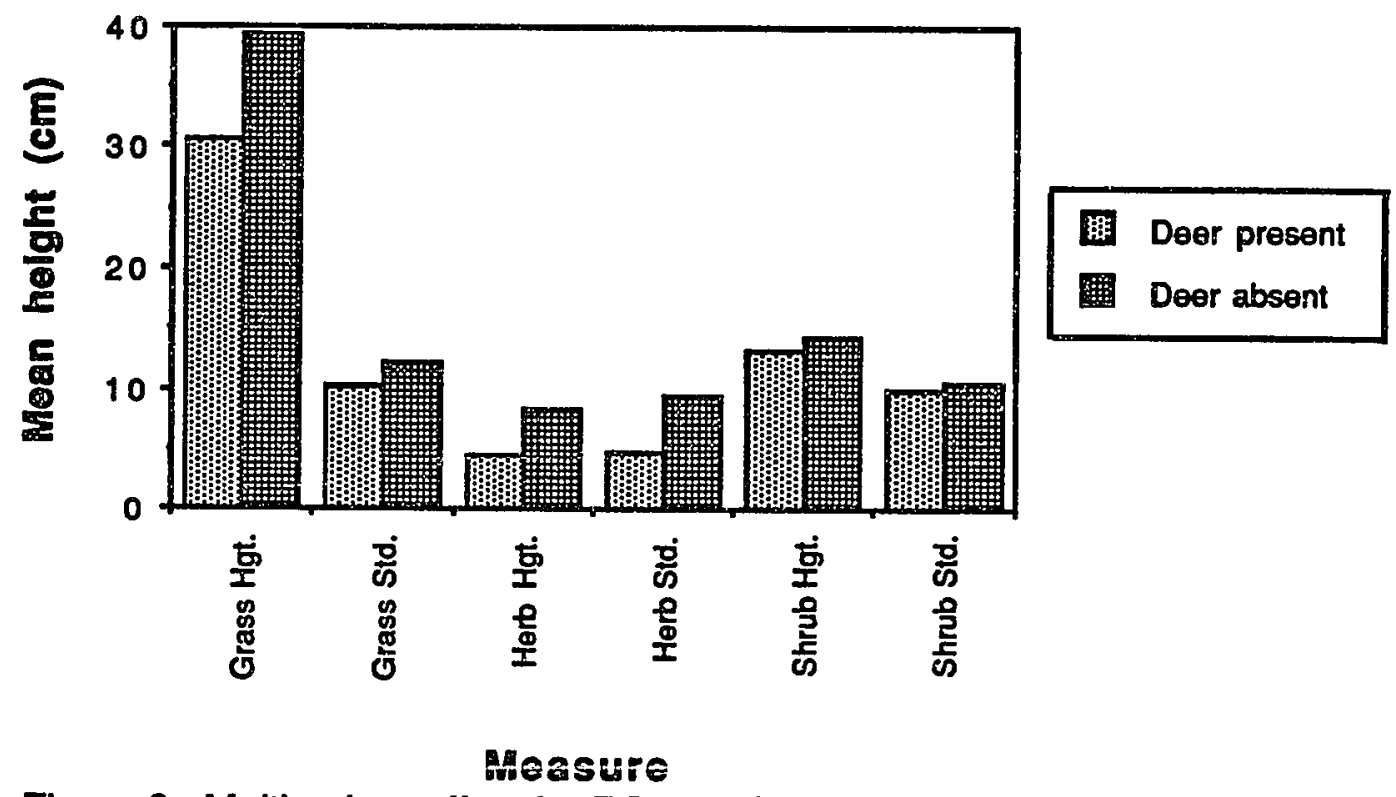

Figure 2. Multivariate effect for RCB ANOVA of Upland Area in April 1993. The main effect is Treatment (Deer present or Deer absent). The Block is a matched pair site. 
Table 3. Univariate tests (RCB ANOVA) of Mean Plant Height and Standard Deviation in Plant Heights for three categories of plants (Grass, Herb and Shrub) in the Upland Area.

Main Effect: Deer Present/Absent (April 1993)

\begin{tabular}{lcrrr}
\hline VARIABLE & DF & \multicolumn{1}{c}{ MS } & \multicolumn{1}{c}{ F } & PROB \\
\hline Grass Hgt. & 1,14 & 560.563 & 24.819 & $>0.000$ \\
Grass Std. Dev. & 1,14 & 28.149 & 9.716 & 0.008 \\
Herb Hgt. & 1,14 & 106.861 & 4.324 & 0.056 \\
Herb Std. Dev. & 1.14 & 164.971 & 5.336 & 0.037 \\
Shrub Hgt. & 1,14 & 9.656 & 0.339 & 0.570 \\
Shrub Std. Dev. & 1,14 & 2.149 & 0.158 & 0.697 \\
Main Effect: Deer Present/Absent (July 1993) & & & \\
Grass Hgt. & 1,14 & 685.548 & 11.807 & 0.004 \\
Grass Std. Dev. & 1,14 & 20.667 & 1.699 & 0.213 \\
Herb Hgt. & 1,14 & 121.686 & 1.357 & 0.263 \\
Herb Std. Dev. & 1.14 & 30.220 & 2.503 & 0.136 \\
Shrub Hgt. & 1,14 & 121.980 & 1.028 & 0.328 \\
Shrub Std. Dev. & 1,14 & 2.296 & 0.073 & 0.792
\end{tabular}


plots; the minimum detectable difference was $8.6 \mathrm{~cm}$ for herb height and 14.0 $\mathrm{cm}$ for shrub height.

By the summer, in the dry season, the only detectable difference between matched plots was shorter grass in the plots accessible to deer. For the measurements in July, the RCB MANOVA showed no detectable difference in proportion for grass, herb, or shrub height between enclosed and non-enclosed matched pair plots (Table 2). The Univariate test (RCB ANOVA) for grass height was significant (Table 3); in July, mean grass height was lower in the open plots $(62.7 \mathrm{~cm})$ than the enclosed plots $(72.3 \mathrm{~cm})$. Again, neither herb or shrub height varied significantly between the deer present and deer absent plots; the minimum detectable difference was $12.6 \mathrm{~cm}$ for herb height and $15.8 \mathrm{~cm}$ for shrub height.

There was no detectable change in species composition as a result of deer browsing in the Upland area over the nine month period from October to July. The RCB MANOVA indicated no significant changes in species composition between enclosed and open matched pair plots for the first five month period (October to April) or the next three month period (April to July). The Univariate tests also showed no significant differences in mean frequency of occurrence for individual species. Mean minimum detectable difference for all plant species was a difference in occurrence in 4.9 plot quadrats in April and 4.6 plot quadrats in July. 
Many species were present in only a few of the fifteen paired plots and could not be evaluated by the statistical tests. However, blackberry (Rubus ursinus), french broom (Genista monspessulana), coast live oak (Quercus agrifolia), coffeeberry (Rhamnus californica), snowberry (Symphoricarpos) and Bolander pea (Lathyrus vestitus) were more abundant in the fenced plots at the time of the final measurement (Table 4). On the other hand, poison oak (Toxicodendron diversilobum) was more abundant in the open plots.

For french broom, the difference in the height of plants between matched pair plots was dramatic in the one pair of plots in which it was present. In January 1994, the total height of all broom plants was $488 \mathrm{~cm}$ in the fenced plot and $83 \mathrm{~cm}$ in the open plot. The three plants in the fenced plot were from 1 to $2 \mathrm{~m}$ tall, while the three plants in the open plot were browsed by deer and were from 20 to $32 \mathrm{~cm}$ tall. The fenced plants produced seed while the open plants did not.

Deer browsing caused no significant change in plant cover at ground level or the above ground level in the Upland over the period of the study. The RCB MANOVA showed no detectable difference in proportions of plant cover for bare ground, grass, herbs or shrubs at ground level or one-half meter between the enclosed and open matched pair plots. Univariate tests also indicated no significant changes. The mean minimum detectable difference was $27.1 \mathrm{~cm}$ for 
Table 4. Occurrence of Selected Species in plot quadrats in the Upland Area.

\begin{tabular}{lcccccc} 
& $\begin{array}{l}\text { Baseline } \\
\text { (Oct '92) }\end{array}$ & \multicolumn{2}{c}{$\begin{array}{l}\text { Remeasure } \\
\text { (April '93) }\end{array}$} & \multicolumn{3}{c}{$\begin{array}{l}\text { Remeasure } \\
\text { (July '93) }\end{array}$} \\
\hline Deer & Present & Absent & Present & Absent & Present & Absent \\
\hline Blackberry & 45 & 28 & 51 & 48 & 52 & 63 \\
Broom & 1 & 1 & 3 & 5 & 3 & 9 \\
Coffeeberry & 0 & 0 & 0 & 0 & 0 & 3 \\
Oak & 0 & 1 & 1 & 1 & 0 & 2 \\
Pea & 2 & 1 & 2 & 10 & 2 & 27 \\
Poison Oak & 19 & 35 & 133 & 108 & 102 & 86 \\
Snowberry & 0 & 0 & 1 & 25 & 1 & 8
\end{tabular}


ground level cover and $5.6 \mathrm{~cm}$ for cover at one-half meter. There was not sufficient data for analysis at one meter.

The results also showed that it is important to use a matched pair design to assess the effects or deer browsing. In the Upland, the Block effect was significant for the multivariate analyses of plant height in April and July and nine of twelve measures in the univariate analyses. The Block effect was significant for both multivariate analyses of species composition and thirteen of twentyeight measures in the univariate analyses. Similarly, the Block effect was significant for both multivariate analyses of plant cover and four of eight univariate measures.

\section{Understory-Seaside}

There was no statistical evidence of differential browsing among the six plant growth categories for the Seaside area over the six month period from December 1992 to June 1993; however deer browsing did cause a reduction in grass height. The RCB MANOVA indicated no significant difference in proportion of the six categories for plant growth, however the Univariate test was significant for grass height. In June, mean grass height was shorter in the open $(21.5 \mathrm{~cm})$ than the fenced plots $(26.3 \mathrm{~cm})$. Neither herb nor shrub height varied significantly between the deer and no deer plots; the minimum detectable difference was $6.7 \mathrm{~cm}$ for herb height and $19.1 \mathrm{~cm}$ for shrub height. 
For the final three month period from June to September, there was again no evidence of differential browsing; however, in this period, the dry season, shrub height was reduced by deer. The RCB MANOVA showed no signiiicant difference in proportion for plant growth for the six categories, but the Univariate test was significant for shrub height. In September, mean shrub height was lower in the open $(14.1 \mathrm{~cm})$ than the fenced plots $(19.0 \mathrm{~cm})$. Grass height and herb height did not vary significantly between the deer present and deer absent plots; in September, the minimum detectable difference was 28.5 $\mathrm{cm}$ for grass height and $3.8 \mathrm{~cm}$ for herb height.

Deer browsing clearly impacted the species composition in the seaside area, but only after the first six month period. For the first six month period from December to June, the RCB MANOVA showed no significant proportional changes in species composition (Table 5) between the enclosed and nonenclosed matched pair plots; however, for the three month period from June to September, the RCB MANOVA did show a proportional shift in species composition. Abundances for lotus, mock heather, and sagewort were proportionately greater (Figure 3) in the fenced (deer absent) plots. Dune sedge had a proportionately greater abundance in the deer present plots.

Deer browsing decreased the abundance of Lotus, a low growing herb, for the entire measurement period, and also decreased the abundance of Mock Heather, a shrub, for the first six month period. For the period from December 
Table 5. Multivariate test (RCB - MANOVA) of Species composition in the Seaside Area.

\begin{tabular}{lcccc}
\hline \multicolumn{1}{c}{ SOURCE } & WILKS' LAMDA & DF & F & PROB \\
\hline For June, 1993 & & & & \\
Deer & 0.077 & 12,1 & 1.000 & 0.663 \\
Present/Absent & & & & \\
For September, 1993 & & & & \\
Deer & 0.000 & 12,1 & 316.127 & 0.044 \\
Present/Absent & & & &
\end{tabular}




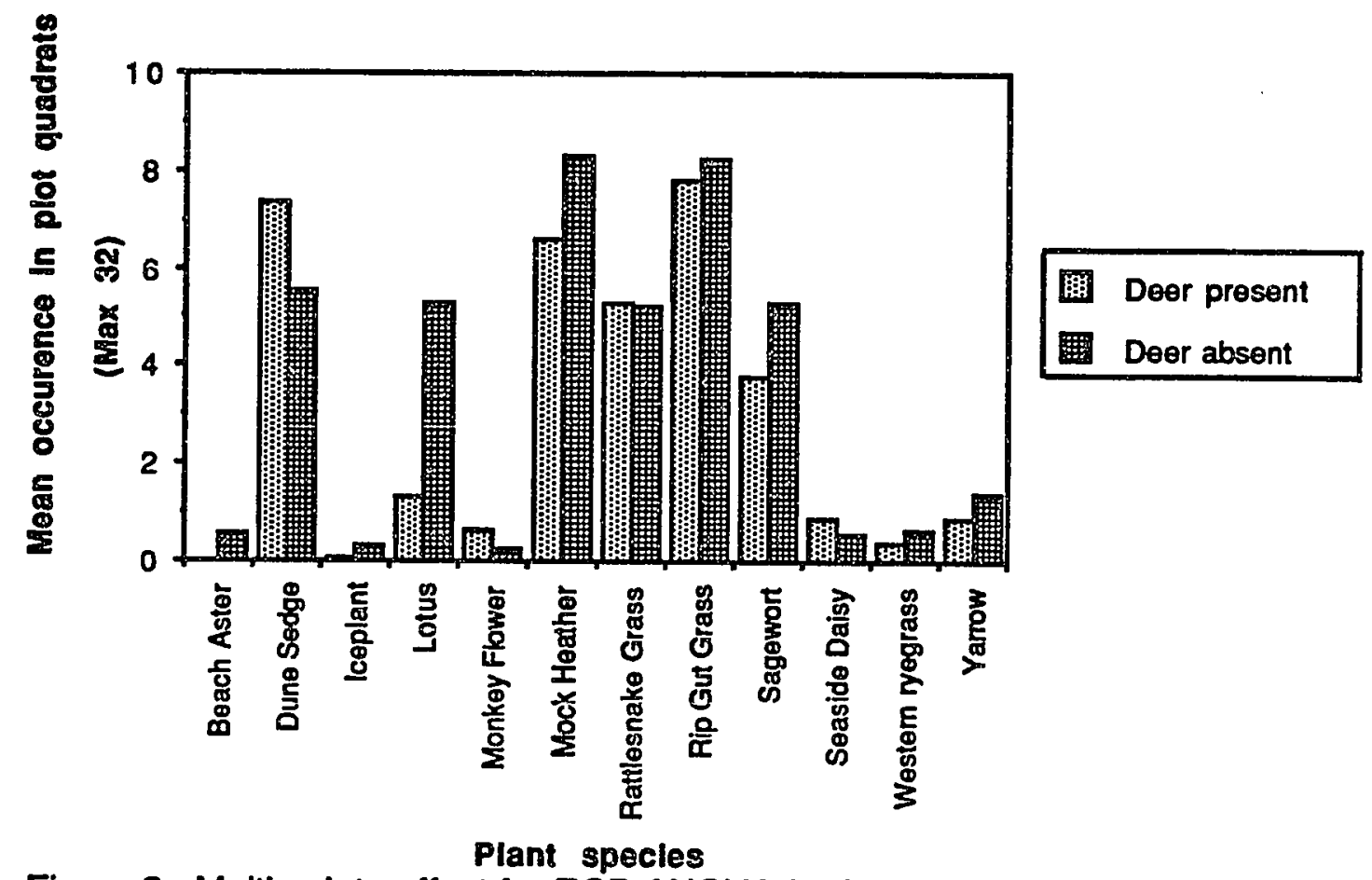

Figure 3. Multivariate effect for RCB ANOVA for frequency of occurrence of species in plot quadrats for Seaside Area in April 1993. The main effect is Treatment (Deer present or Deer absent). The Block is a matched pair site. 
to June, univariate tests (Table 6) indicated a greater mean frequency of occurrence (Figure 4) of Mock Heather (Ericameria ericoides) in the fenced plots (9.2) than the open (7.9) and a greater mean frequency of occurrence of Lotus (Lotus spp.) in the fenced plois (19.0 fence) than the open (14.1). For the period from June to September, the univariate tests again showed a greater mean frequency of occurrence of lotus in the fenced plots (5.3) than the open (1.3). The mean minimum detectable difference for all other species was a difference in occurrence in 6.6 plot quadrats in June and 5.6 plot quadrats in September.

Iceplant (Camobrotus spp) occurred in just one pair of matched plots; however, iceplant appeared to have sustained growth only inside the exclosure. There were many small iceplants inside the fence, some of which were not in the plot, while iceplant was nearly absent in the surrounding areas outside the fence.

For the seaside area, deer browsing caused no significant change in plant cover at the ground level or the above ground level over the nine month period (Dec-Sept). The RCB MANOVA showed no detectable difference in proportions of plant ccver for bare ground, grass, herbs, and shrubs at ground level or at one-half meter between the enclosed and open matched pair plots. Univariate tests for the seaside sites also indicated no significant changes. The 
Table 6. Univariate tests (RCB ANOVA) of Occurrence of Specific Species in plot quadrats in the Seaside Area for June 1993.

Main Effect: Deer Present/Absent

\begin{tabular}{crrrr}
\hline VARIABLE & \multicolumn{1}{c}{ DF } & \multicolumn{1}{c}{ MS } & F & PROB \\
\hline Beach Aster & 1,12 & 1.385 & 1.929 & 0.190 \\
Bracken Fern & 1,12 & 5.538 & 1.774 & 0.208 \\
Dune Sedge & 1,12 & 22.154 & 2.420 & 0.146 \\
Lotus & 1,12 & 162.500 & 7.863 & 0.016 \\
Monkey Flower & 1,12 & 0.346 & 1.929 & 0.190 \\
Mock Heather & 1,12 & 9.846 & 4.892 & 0.047 \\
Monterey Pine & 1,12 & 0.615 & 1.684 & 0.219 \\
Rattle Snake Grass & 1,12 & 12.462 & 0.541 & 0.476 \\
Ripgut Grass & 1,12 & 4.654 & 0.226 & 0.643 \\
Sagewort & 1,12 & 22.154 & 2.689 & 0.127 \\
Seaside Daisy & 1,12 & 0.615 & 1.684 & 0.219 \\
Yarrow & 1,12 & 0.346 & 0.054 & 0.820
\end{tabular}




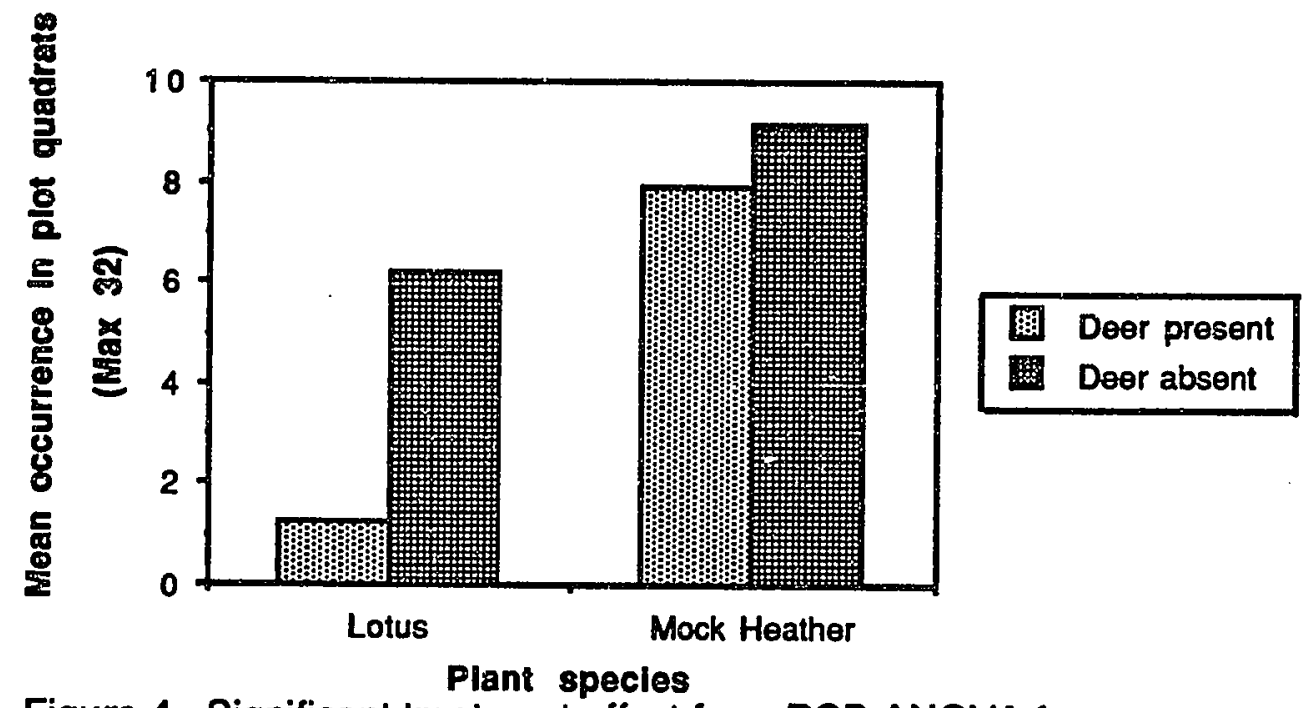

Figure 4. Significant treatment effect from RCB ANOVA for occurrence of Lotus and Mock Heather in plot quadrats for Seaside in June 1993. Main effect is Treatment (Deer present and Deer absent) and Block is the matched pair site. 
mean minimum detectable difference for cover was $16.7 \mathrm{~cm}$ at ground level and $20.7 \mathrm{~cm}$ at one-half meter. There was not sufficient data for analysis at one meter.

The results for the Seaside clearly showed the importance of the matched pair design in assessing the effects of deer browsing. The Block effect was significant for all measures and analyses of plant height. For the assessment of change is species composition, the Block effect was significant for both multivariate analyses and twenty of twenty-four univariate measures. Finally, the Block effect was significant for both mutivariate analyses of plant cover and eight of eleven univariate measures.

\section{Deer census}

The number of deer counted at Asilomar decreased over the year (Figure 5). Four deer census counts between December 1992 and February 1993 ranged from 15 to 22 with 4-5 fawns. Counts from April to September 1993 ranged from 0 to 10 with from 1-5 fawns. Two resident cohorts (a female and her offspring) were observed consistently in the same locations over the study period. These counts contrast sharply with counts taken in the summer of 1992. A report on census counts for the summer of 1992 (Smith 1992) before the cessation of private feeding, stated that 45 deer were using the park. The 1992 report did not include a fawn count. 


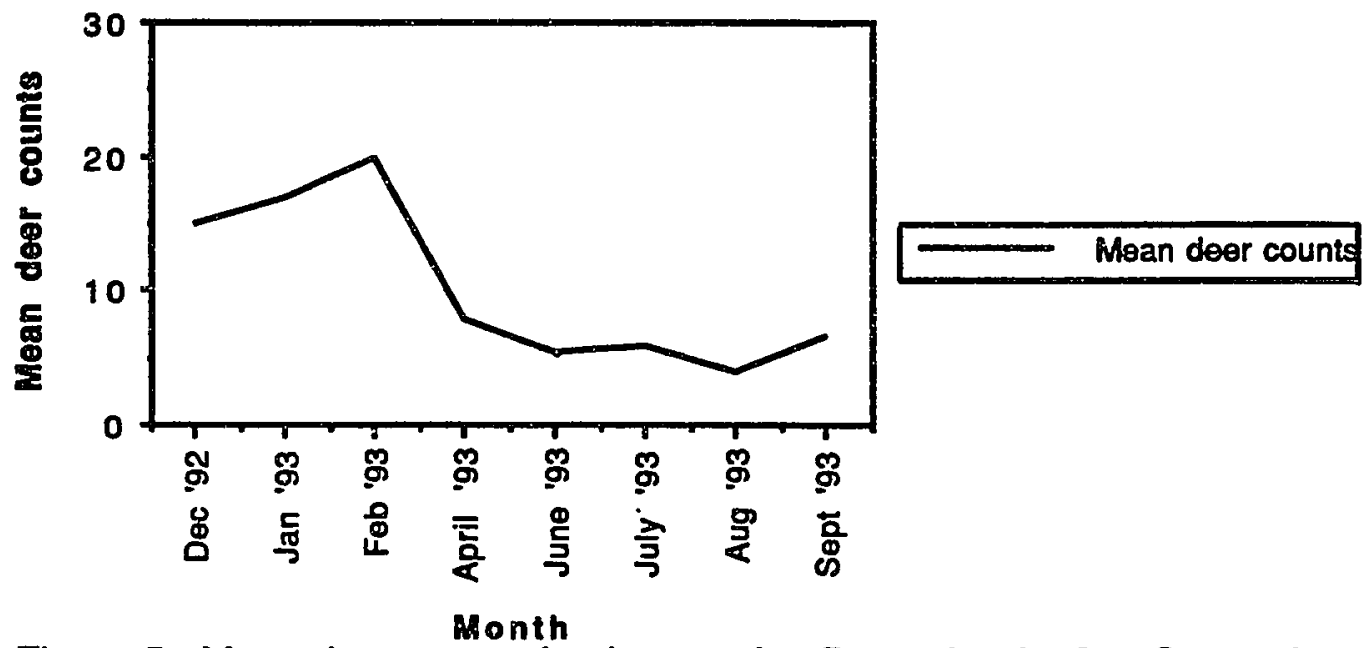

Figure 5. Mean deer counts for the months, December 1992 to September 1993. 
The private feeding, which was terminated in the late summer of 1992, took place at the same time of the day at a house near the beach just north of Asilomar. The deer would follow well delineated trails through Asilomar to gather at the residence for the daily feeding. Over the year after cessation of feeding, deer stopped moving through the park to the feeding station.

\section{DISCUSSION}

Plant height was reduced by deer browsing at Asilomar. These results confirm findings from exclosure studies with white-tailed deer in the Eastern United States (Graham 1958, Tierson et al. 1966, Blewett 1976, Kroll et al. 1986, Tilghman 1989, Anderson 1994). Tilghman (1989) reported that plant height was reduced by white-tailed deer at high densities in an uncut forest in Pennsylvania. Anderson (1994) also reported lower plant height in sampling areas accessible to deer in llinois.

Grass height was reduced over the year, herb height was impacted in the spring, and shrub height was reduced in late summer. This pattern would confirm the results of rumen analysis of black-tailed deer (Taber 1956,Schauss and Coletto 1986) that showed a higher percentage of herbs in the diet in spring and a higher percentage of shrubs in the diet in summer and fall. In California the principal growth period for herbs and shrubs is in the spring when there is both adequate moisture and a sufficiently high temperature. The principal 
growth period for grasses is in the winter after the first adequate precipitation (usually in October). Shrubs are browsed in the summer and fall, the hot dry season, when the herbs have died back and the grass is no longer green.

A reduction in both plant height and variability in plant height due to browsing would have variable effects on restoration. The responses of plants to herbivory (e.g. browsing) vary greatly (Lubbers and Lechowicz 1989). In most cases, yearly defoliation causes smaller plants and fewer flowering plants (Jameson 1963, Wilson and Price 1980, Anderson 1994). In a few cases, plant reproduction can be unaffected or enhanced by herbivory (Paige and Whitham 1987). The reduction of the variability in herb height in the spring indicates that deer are browsing the tallest herbs. We can assume that most but not all of the native and non-native herbs would be negatively impacted over the long term. The reduction in the height of non-native annual grasses would not negatively impact restoration; however, we were unable to make an important distinction in the summer between Bromus diandrus, an invasive annual grass, and Bromus carinatus, a native perennial. Native perennial grasses vary in their tolerance to grazing (Blumler 1992); Bromus carinatus seems to prosper at sites not open to cattle grazing. Deer browsing causes a reduction in shrub height and consequently an undesirable reduction in the density of the understory. Recreating a lush native understory is a part of the restoration plan. 
Some of the impacts of deer on species composition at Asilomar are positive in terms of the Asilomar restoration plan. Some plants of invasive nonnative broom are browsed nearly to the ground. These heavily browsed broom plants do not flower or produce seed. Deer seem to help inhibit the return of the non-native iceplant that was removed in the seaside area. The spread of native poison oak is not inhibited by deer; poison oak plants are shorter but cover a larger area in the plots accessible to deer. Although the oaks and pines are both native species, preservation of the Monterey pine forest is the prime concern of the CDPR. The Monterey pine forest at Asilomar is part of the largest of only three native Monterey pine stands in the United States. Deer browse on coast live oaks and prevent the regeneration and growth of some oaks which would compete with the pines.

However, on the negative side, deer may be inhibiting the growth and propagation of many native species. Lotus, a low growing ground cover, that could stabilize some bare areas in the seaside section is heavily impacted. Other desirable natives may be impacted. Blackberry, coffeeberry, snowberry, Bolander pea, beach aster and western nyegrass were less abundant in the open plots at the time of the final measurement. Deer seem to remove flowers which could affect seed propagation of native species (Anderson 1994).

The deer population in the park is much lower than in the previous year probably due to the cessation of private ieeding. There appear to be two 
resident cohorts (adult female and her offspring) in the forested area. The ratio of fawns to females is less than one indicating slow growth for that year. The deer density at Asilomar (22 deer/km2) is still far greater than the density recommended by Alverson (1988) and Anderson (1994) (2-6 deer/km2) as necessary to preserve native understory species from white-tailed deer in the eastern United States. Using their criteria, one resident cohort would be desirable; however, the two cohorts at Asilomar are in separate areas of the park that are largely divided by fencing.

The paired plot design was essential in determining the impact of deer on vegetation because of the variability in the plant communities within each sampling area. The paired plot exclosure design isolates the changes in plant height, cover, and species composition due to the impact of deer, from changes due to other causes. Changes in the overstory impact the species composition of the understory (Stearns 1951, Arnold and Verme 1964, Lawrence and Biswell 1972, Mclnnes et al. 1992). Shade adapted plants decline and sunlight adapted plants increase when the overstory is opened. The Monterey pine forest at Asilomar is in a continuing process of change and management. The trees which form the overstory canopy are more than 76 years old, an age that is considered overmature (Smith 1992). Trees are being removed because of disease and beetle infestation. In some areas, the forest floor is more open, thus sunnier and drier. 
In our study, we randomly picked paired plot sites from the entire park (divided into two sections) because we wanted to consider all possible impacts of deer browsing. We did not target specific areas or plant species. However, if targeting specific species (such as native grasses) were desired, it could be easily incorporated into the design. Heights of individual species in each quadrat for each plot could be recorded.

To increase the density of the understory, we recommend propagating and planting native species not negatively impacted by deer. Deer tend to eat the tallest plants (Anderson 1991). After more cover is established, more sensitive species can be planted away from deer trails and bedding sites and under the cover of less sensitive species.

Plants that have been shown to be negatively impacted can be protected by exclosures especially during flowering. The experimental exclosures will serve as small reservoirs for impacted plants. Larger areas could be fenced until the vegetation can recover. 


\section{LITERATURE CITED}

Alverson, W. S. D. M. Waller, and S. L. Solheim. 1988. Forests too deer: edge effects in northem Wisconsin. Conservation Biology 2:348-358.

Anderson, R. C. 1994. Height of white-flowered trillium (Trillium grandiflorum) as an index of deer browsing intensity. Ecological Applications 4:104-109.

Anderson, R. C., and O. L. Loucks. 1979. White-tailed deer (Odocoileus virginianus) influence on the structure and composition of Tsuga canadensis forests. Journal of Applied Ecology 16:855-861.

Arnold, D. A., and L. J. Verme. 1964. Ten year's observation of an enclosed deer herd in northern Michigan. Transactions of the North American Wildlife Conference 29:422-430.

Beals, E. W., G. Cottam, and R. J. Vogl. 1960. Influence of deer on the vegetation of the Apostle Islands, Wisconsin. Journal of Wildlife Management 24(1):68-80.

Bloom, S. A. 1981. Similarity indexes in community studies; potential pitfalls. Marine Ecology, Progress Series 5:125-128.

Bray, J. R., and J. J. Curtis. 1957. An ordination of the upland forest communities in southern Wisconsin. Ecological Monographs 27:325-349. 
Crane, H. S., and D. A. Jones. 1953. Initial proof of mule deer fawns breeding is found in Utah. Journal of Wildlife Management 17:225.

Dasmann, R. F., and R. D. Taber. 1955. A comparison of four deer census methods. California Dept. of Fish and Game 41:225-228.

Dasmann, R. F., and R. D. Taber. 1956. Determining structure in Columbian black-tailed deer populations. Journal of Wildlife Management 20(l):78-83.

Diamond J. 1992. Must we shoot deer to save nature? Natural History August:2-8.

Garrot, R. A., D. B. Siniff, J. R. Tester, T. C. Eagle, and E. D. Plotka. 1992. A comparison of contraceptive technologies for feral horse management. Wildife Society Bulletin 20:318-326.

Garrott, R. A., P. J. White, and C. A. Vanderbilt White. 1993. Overabundance: an issue for Conservation Biologists. Conservation Biology 4:946-949.

Graham, S. A. 1958. Results of deer exclosure experiments in the Ottawa National Forest. Transactions of the North American Wildlife Conference 23:478-490.

Hickman, J. C. ed. 1993. The Jepson manual: higher plants of California. University of California Press, Berkeley, California. 
Hough, A. F. 1965. A twenty-year record of understory vegetational change in a virgin Pennsylvania forest. Ecology 46(3):370-373.

Jameson, D. J. 1963. Response of individual plants to harvesting. Botanical Review 29:532-594.

Kershaw, K. A., and J. H. Looney. 1985. Quantitative and Dynamic Plant Ecology. Edward Arnold, 4-29 pp.

Lawrence, G., and H. Biswell. 1972. Effect of forest manipulation on deer habitat in Giant Sequoia. Journal of Wildlife Management 36(2):595-605.

Lubbers, A. E., and M. J. Lechowicz. 1989. Effects of leaf removal on reproduction vs. below ground storage in Trillium grandiflorum. Ecology 70(1):85-96.

MicInnes, P. F., R. J. Naiman, J. Pastor, and Y. Cohen. 1992. Effects of moose browsing on vegetation and litter of the boreal forest, Isle Royale, Michigan, USA. Ecology 73(6):2059-2075.

Ozoga, J. J., and L. J. Verme. 1982. Physical and reproductive characteristics of a supplementally-fed white-tailed deer herd. Journal of Wildlife Management 46:281-30I.

Paige, K. N., and T. G. Whitham. 1987. Overcompensation in response to mammalian herbivory: the advantage of being eaten. American Naturalist 129:407-416. 
Porter, W. F., N. E. Mathews, and H. B. Underwoods. 1991. Social organization in deer: implications for localized management. Environmental Management 15:809-814.

Robinette, W. L., and J. S. Gashwiler. 1950. Breeding season, productivity, and fawning period of the mule deer in Utah. Joumal of Wildlife Management 14:457-469.

Schauss, M. E., and H. J. Colletto. 1986. Population characteristics and management of black-tailed deer in the Mt. Hamilton Range of California.

Smith, S. G. 1992. Asilomar Conference Grounds forest ecology study and forest management plan. Administrative draft.

Taber, R. D. 1956. Deer nutrition and population dynamics in the north coast range of California. Transactions of the North American Wildlife Conference $21: 160-172$.

Taber, R. D., and R. F. Dasmann. 1958. The black-tailed deer of the chaparral. Game Bulletin No 8. Cal Fish and Game, 62 pp.

Tierson, W. C., E. F. Patric, and D. F. Behrend. 1966. Influence of white-tailed deer on the logged northern hardwood forest. Journal of Forestry $64: 801-$ 805.

Tilghman, N. G. 1989. Impacts of white-tailed deer on forest regeneration in northwestern Pennsylvania. Journal of Wildlife Management 53:524-532. 
Wilson, M. F., and P. W. Price. 1980. Resource limitation of fruit and seed production in some Asclepias species. Canadian Journal of Botany 58:2229-2233.

Zar, J. H. 1984. Biostatistical Analysis. Prentice-Hall, Inc, 222-228 pp.. 